[94]ジアリルベンゼンホスホネートの共重合 (1964 年 4 月 11 日受理)

橋 本 静 信*・古川 功*

\begin{abstract}
要 旨 ジアリルベンゼンホスホネート(DABP) と,メチルメタクリレート(MMA) およびスチレン (St) のモノマーの反応性比を $70^{\circ} \mathrm{C}$ で測定し, それぞれ MMA-DABP, $r_{1}=22.96, r_{2}=0.135$; St-DABP, $r_{1}=28.97, r_{2}=0.027$ を得た。DABP の MMA および St との共重合反応では DABP モノマーの反応性 比はきわめて小さいが, 他のアリル化合物に比べると多少大きい值を有する。コポリマーのベンゼン溶液粘度 はモノマー組成中の DABP 含有量の増加従って堿少する。赤外線吸収スペクトルから DABP モノマーは 分子内で環を形成しているものと考えられる。
\end{abstract}

\section{1. 緒言}

近年耐燃性樹脂として多数の有機リン化合物が研究さ れ，これらリン化合物を用いた単独または共重合樹脂に 関する報告は非常に多い"1)。しかし，大部分のものは生成 樹脂の性状に関する研究であって，共重合反応について はわずかにジェチルビニルホスホネートとスチレン2， ラウリルメタクリレートとジアリルベンゼンホスホネー ト diallyl benzenephosphonate (DABP), ジアリルブ チルホスホネート, ジェチルアリルホスホネード)など の報告が見られるにすぎない。

そこで筆者らは有機リン化合物の中で代表的モノマー として DABP を選び,これとメチルメタクリレート (MMA) およびスチレン (St) の共重合反応について研 究を行なった。

\section{2. 実験方法}

\section{1 モノマー}

DABP はヘンザンを出発原料として無水塩化アルミ ニウムの存在下で, 三塩化リンを作用させるフリーデル クラフト型の反応でまずフェニルジクロロホスヒンを合 成, これを塩素と無水リン酸で処理してフェニルホスホ ニックジクロライドとし, さらにピリジンの存在下でア リルアルコールでェステル化して得る既報”の方法によ った。

$$
\begin{aligned}
\mathrm{C}_{6} \mathrm{H}_{6} \stackrel{\mathrm{PCl}_{3}+\mathrm{AlCl}_{3}}{\longrightarrow} \mathrm{C}_{6} \mathrm{H}_{5} \mathrm{PCl}_{2} \cdot \mathrm{AlCl}_{3} \\
\stackrel{\mathrm{POCl}}{\longrightarrow} \mathrm{C}_{6} \mathrm{H}_{5} \mathrm{PCl}_{2} \stackrel{\mathrm{Cl}_{2}+\mathrm{P}_{2} \mathrm{O}_{5}}{\longrightarrow} \mathrm{C}_{6} \mathrm{H}_{5} \mathrm{P}(\mathrm{O}) \mathrm{Cl}_{2} \\
\stackrel{\mathrm{CH}_{2}}{\stackrel{\mathrm{CHCH}_{2} \mathrm{OH}}{\mathrm{C}_{5} \mathrm{H}_{5} \mathrm{~N}}} \rightarrow \mathrm{C}_{6} \mathrm{H}_{5} \mathrm{P}(\mathrm{O})\left(\mathrm{OCH}_{2} \mathrm{CH}=\mathrm{CH}_{2}\right)_{2}
\end{aligned}
$$

沸点 $120 \sim 123^{\circ} \mathrm{C} / 0.23 \mathrm{mmHg}$, 届折率 $n_{\mathrm{D}}^{25} 1.5124$, ヨウ素価 214.38 (計算值：213.2), リン含有率 $12.93 \%$ (計算值： $13.01 \%$ ), 純度 $99.4 \%$ (リン含有率ならびに

\footnotetext{
* 同志社大学工学部工業化学教室(京都市上京区鳥丸今出川)
}

ヨウ素価による)。

MMA は市販品を常法により精製し, 沸点 43〜 $43.5^{\circ} \mathrm{C} / 90 \mathrm{mmHg}$ の留分を使用, St は同様市販品を精 製して沸点 $56 \sim 57^{\circ} \mathrm{C} / 38 \mathrm{mmHg}$ の留分を使用した。

2.2 重 合

重ク口ム酸混液で処理した後, 水蒸気洗浄をして十分 乾燥した重合管にモノマー混合物約 0.01 モルを入れ, さらに過酸化ベンゾイルを重合開始郕としてモノマーに 対し 2 モル \% 加え窒素で置換して封管した。重合温度 は $70 \pm 0.1^{\circ} \mathrm{C}$ で, 重合率が約 $10 \%$ 以下のところで重 合を停止し, 内容物を約 $10 \mathrm{cc}$ のクロロホルムに溶解し て, MMA コポリマーでは石油ベンジン, St コポリマ 一ではメタノールおのおの $150 \mathrm{cc}$ で再沈殿した。この 再沈殿操作を 2 回以上くり返した後, 减圧下で $50^{\circ} \mathrm{C}$ で 恒量となるまで乾燥して初期ポリマーを収得した。

\section{3 コポリマー中のリンの定量}

コポリマー中に含有するリンは, 過塩素酸で酸化分解 してリン酸としてこれをさらにリンモリブデン酸ブルー として比色定量する C. L. Arcus ら²の方法を用いた。 小型ケールダールフラスコに試料約 $10 \mathrm{mg}$ と $70 \%$ 過塩素酸 $2 \mathrm{cc}$ を入れ，初めの 10 分間はごく小さな火 でゆっくりと加熱後，火を少し強くして過塩素酸が加熱 還流する程度に 40 分間酸化分解すると内容物は無色透 明となる。さらに数分間加熱して分解を完結して放冷, 蒸留水 $5 \mathrm{cc}$ を加えて 沸騰した水浴中で 15 分間加熱, 冷後水を加えて全量を $100 \mathrm{cc}$ としてこの中の $25 \mathrm{cc}$ を とり, $50 \mathrm{cc}$ メスフラスコ中で $70 \%$ 過塩素酸 $3.5 \mathrm{cc}$, アミドール試薬*1 $4.5 \mathrm{cc}$ ，モリブデン酸アンモニウム水 溶液 $3.5 \mathrm{cc}$ を順次加えて蒸留水で全量を $50 \mathrm{cc}$ として 30 分間放置後, $720 \mathrm{~m} \mu$ で吸光度を測定する。同様にし て試料を含まない溶液の吸光度 (空試験值) を測定して, その差をあらかじめ作成しておいた検量線にあてはめて リンの含有率を求めた。

*1 水 $60 \mathrm{cc}$ にアミドール $1 \mathrm{~g}$ と亜硫酸水素ナトリウム $10 \mathrm{~g}$ を溶解したものと，水 $20 \mathrm{cc}$ に潩硫酸 $2.7 \mathrm{cc}$ を加えたものを混 合する。 
この比色定量法を用いて純粋な $\left(\mathrm{C}_{6} \mathrm{H}_{5} \mathrm{O}\right)_{8} \mathrm{P}(\mathrm{O}),(\mathrm{P}$ : 9.49\%) を測定したところ P: $9.43 \%$ となり，その実 験誤差は $-0.06 \%$ であり十分信頼しうる値を得た。

リン含有率よりコポリマー中の DABP のモル分率の 算出は (1) 式によった。

$$
\begin{gathered}
d\left[M_{2}\right]=\frac{x \cdot M W_{1}}{x \cdot M W_{1}+(12.93-x) M W_{2}} \\
\text { こで } \quad x: \text { コポリマー中のリン } \% \\
M W_{1}: \mathrm{M}_{1} \text { モノマーの分子量 } \\
M W_{2}: \mathrm{M}_{2} \text { モノー (DABP) の分子量 } \\
12.93: \mathrm{DABP} \text { モマー中のリン } \%
\end{gathered}
$$

Table 1. Copolymerization of methyl methacrylate (MMA) and diallyl benzenephosphonate (DABP) at $70^{\circ} \mathrm{C}$.

\begin{tabular}{c|c|c|c|c|c|c|c|c}
\hline \hline No. & $\begin{array}{c}\text { Mol frac- } \\
\text { tion of } \\
\text { DABP } \\
{\left[\mathrm{M}_{2}\right]}\end{array}$ & $\begin{array}{c}\text { Monomer } \\
\text { mixture } \\
\text { weight } \\
(\mathrm{g})\end{array}$ & $\begin{array}{c}\text { Initiator } \\
(\mathrm{BPO}) \\
\text { concn. } \\
(\mathrm{mol} \%)\end{array}$ & $\begin{array}{c}\text { Reaction } \\
\text { time } \\
(\mathrm{min})\end{array}$ & $\begin{array}{c}\text { Polymer } \\
\text { yield } \\
(\mathrm{g})\end{array}$ & $\begin{array}{c}\text { Conversion } \\
(\mathrm{mol} \%)\end{array}$ & $\begin{array}{c}\mathrm{P} \text { in } \\
\text { polymer } \\
(\%)\end{array}$ & $\begin{array}{c}\text { Mol fraction } \\
\text { of DABP in } \\
\text { polymer } \\
\left.d \mathrm{M}_{2}\right]\end{array}$ \\
\hline 1 & 0.0859 & 1.0090 & 2.0 & 15 & 0.1178 & 12.97 & 0.153 & 0.0050 \\
2 & 0.2002 & 1.1526 & 2.0 & 15 & 0.0967 & 10.54 & 0.344 & 0.0113 \\
3 & 0.2988 & 1.2918 & 2.0 & 15 & 0.1165 & 12.39 & 0.604 & 0.0199 \\
4 & 0.4022 & 1.4298 & 2.0 & 15 & 0.0981 & 10.23 & 0.921 & 0.0310 \\
5 & 0.4991 & 1.5594 & 2.0 & 15 & 0.1009 & 10.25 & 1.374 & 0.0473 \\
6 & 0.6011 & 1.6959 & 2.0 & 15 & 0.0665 & 6.47 & 2.195 & 0.0786 \\
7 & 0.6986 & 1.8249 & 2.0 & 30 & 0.1227 & 11.10 & 3.549 & 0.1363 \\
8 & 0.7989 & 2.1069 & 2.0 & 30 & $*$ & - & 5.072 & 0.2118 \\
9 & 0.8995 & 2.2436 & 2.0 & 175 & $*$ & - & - & - \\
10 & 0.9461 & 2.3193 & 2.0 & 255 & $*$ & - & - & - \\
\hline
\end{tabular}

* Oily product

Table 2. Copolymerization of styrene (St) and diallyl benzenephosphonate (DABP) at $70^{\circ} \mathrm{C}$.

\begin{tabular}{c|c|c|c|c|c|c|c|c|c|}
\hline No. & $\begin{array}{c}\text { Mol frac- } \\
\text { tion of } \\
\text { DABP } \\
{\left[\mathrm{M}_{2}\right]}\end{array}$ & $\begin{array}{c}\text { Monomer } \\
\text { mixture } \\
\text { weight } \\
(\mathrm{g})\end{array}$ & $\begin{array}{c}\text { Initiator } \\
(\mathrm{BPO}) \\
\text { concn. } \\
(\mathrm{mol} \%)\end{array}$ & $\begin{array}{c}\text { Reaction } \\
\text { time } \\
(\mathrm{min})\end{array}$ & $\begin{array}{c}\text { Polymer } \\
\text { yield } \\
(\mathrm{g})\end{array}$ & $\begin{array}{c}\text { Conversion } \\
(\mathrm{mol} \%)\end{array}$ & $\begin{array}{c}\text { P in } \\
\text { polymer } \\
(\%)\end{array}$ & $\begin{array}{c}\text { Mol fraction } \\
\text { of DABP in } \\
\text { polymer } \\
d\left[\mathrm{M}_{2}\right]\end{array}$ \\
\hline 1 & 0.0991 & 1.0373 & 2.0 & 60 & 0.1146 & 12.45 & 0.027 & 0.0009 \\
2 & 0.1997 & 1.2374 & 2.0 & 60 & 0.1099 & 11.07 & 0.168 & 0.0057 \\
3 & 0.3009 & 1.3800 & 2.0 & 60 & 0.1049 & 10.31 & 0.514 & 0.0177 \\
4 & 0.4004 & 1.4997 & 2.0 & 60 & 0.0856 & 8.40 & 0.650 & 0.0225 \\
5 & 0.4992 & 1.5956 & 2.0 & 60 & 0.0749 & 7.40 & 0.899 & 0.0314 \\
6 & 0.5979 & 1.7127 & 2.0 & 80 & 0.0757 & 7.37 & 1.314 & 0.0468 \\
7 & 0.6999 & 1.8764 & 2.0 & 80 & 0.0500 & 4.60 & 2.050 & 0.0757 \\
8 & 0.7932 & 2.0166 & 2.0 & 80 & $*$ & - & - & - \\
9 & 0.8969 & 2.0938 & 2.0 & 100 & $*$ & - & - & - \\
10 & 0.9789 & 2.2635 & 2.0 & 100 & $*$ & - & - & - \\
\hline
\end{tabular}

* Oily product 


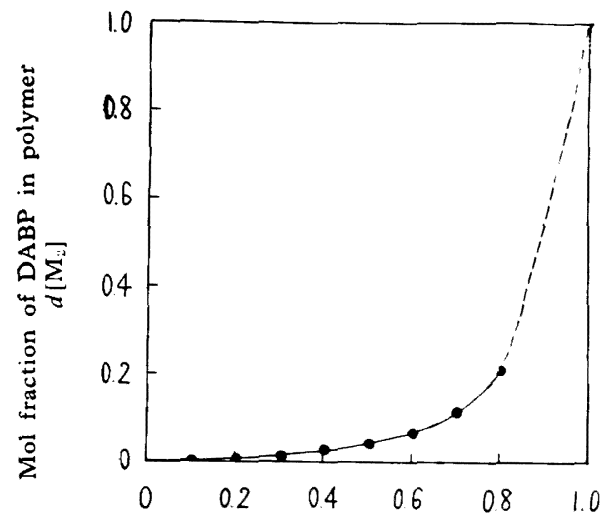

Mol fraction of DABP in feed $\left[\mathrm{M}_{2}\right]$

Fig. 1. Copolymer composition curve for the copolymerization of methyl methacrylate (MMA) $\left[\mathrm{M}_{1}\right]$ and diallyl benzenephosphonate (DABP) $\left[\mathrm{M}_{2}\right]$ at $70^{\circ} \mathrm{C}$.

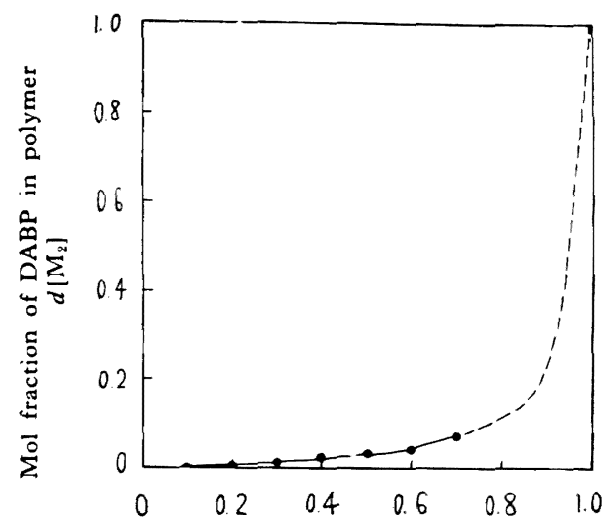

Mol fraction of DABP in feed $\left[\mathrm{M}_{2}\right]$

Fig. 2. Copolymer composition curve for the copolymerization of styrene $(\mathrm{St})\left[\mathrm{M}_{1}\right]$ and diallyl benzenephosphonate (DABP) $\left[\mathrm{M}_{2}\right]$ at $70^{\circ} \mathrm{C}$.

Fig. 1，2 によく現われている。

1 官能性モノマーど5しの共重合反応では共重合体組 成式は (2) 式で表わされる。

$$
\frac{d\left[M_{1}\right]}{d\left[M_{2}\right]}=\frac{\left[M_{1}\right]}{\left[M_{2}\right]} \cdot \frac{r_{1}\left[M_{1}\right]+\left[M_{2}\right]}{\left[M_{1}\right]+r_{2}\left[M_{2}\right]}
$$

しかるに DABP 分子はジフリルフタレートのよ5に 分子内に 2 個のアリル基を有する 2 官能性モノマーであ り,これが MMA, St のよ5な 1 官能性モノマーと共 重合した場合には，この5ちの 1 個が重合反応にあうか っても残りのアリル基の反応性は変化しないと考える と，1官能性モノマーに比較して 2 倍量の官能基を有す
ることになる。したがって DABP の濃度は二重結合 1 個の 1 官能性モノマーの 2 倍量として (2) 式を変形す ると(3) 式となる。

$$
\frac{d\left[M_{1}\right]}{d 2\left[M_{2}\right]}=\frac{\left[M_{1}\right]}{2\left[M_{2}\right]} \cdot \frac{r_{1}\left[M_{1}\right]+2\left[M_{2}\right]}{\left[M_{1}\right]+r_{2} 2\left[M_{2}\right]}
$$

この仮定は, DABP の 2 個のアリル基の反応性は必 ずしも同一であるとは考えられず，またポリマー中の DABP のアリル基はすべて重合したものであるとも考 えられないなど理論的にも少々無理な点もあるが，2官 能性モノマーを取り扱った研究もほとんどこのような考

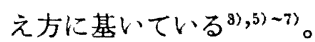

モノマーの反応性比 $\left(r_{1}\right.$ および $\left.r_{2}\right)$ の算出は (3) 式に $\left[M_{1}\right] / 2\left[M_{2}\right]=F, d\left[M_{1}\right] / d\left(2\left[M_{2}\right]\right)=f$ を代入して変形した Fineman-Ross 式（4）を用いた。

$$
\frac{F(f-1)}{f}=r_{1} \cdot \frac{F^{2}}{f}-r_{2}
$$

ここで $F(f-1) / f$ と $F^{2} / f$ の関倸を描くと Fig. 3, 4 に示すような良好な直線関係が得られる。この直線の勾 配と切片より

$$
\begin{array}{ll}
\text { MMA-DABP : } & r_{1}=22.96, r_{2}=0.135 \\
& r_{1} r_{2}=3.099 \\
\text { St-DABP : } & r_{1}=28.97, \quad r_{2}=0.027 \\
& r_{1} r_{2}=0.782
\end{array}
$$

が得られた。

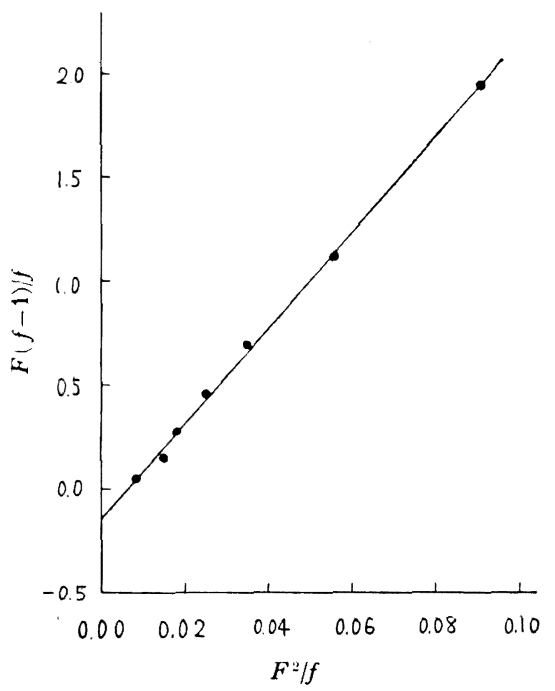

Fig. 3. Determination of $r_{1}$ and $r_{2}$ by the Fineman and Ross method for the copolymerization of methyl methacrylate $\left[\mathrm{M}_{1}\right]$ and diallyl benzenephosphonate $\left[\mathrm{M}_{2}\right]\left(r_{1}=22.96, r_{2}=0.135\right)$. 


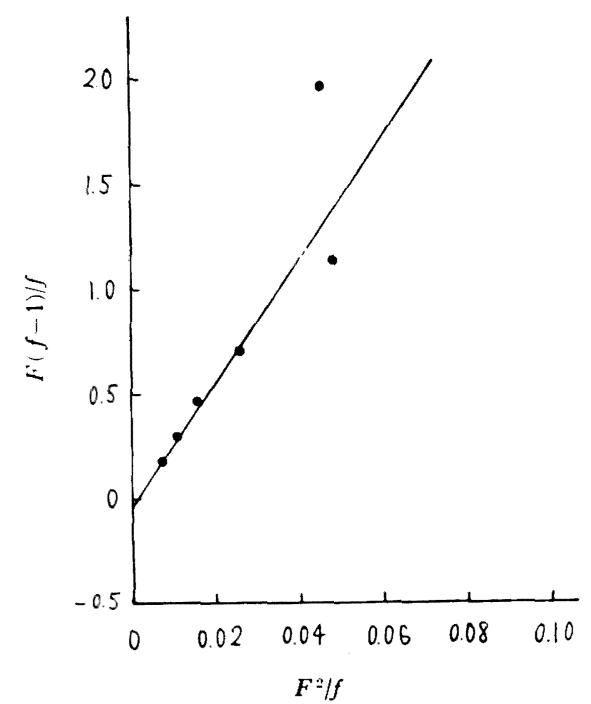

Fig. 4. Determination of $r_{1}$ and $r_{2}$ by the Fineman and Ross method for the copolymerization of styrene $\left[\mathrm{M}_{1}\right]$ and diallyl benzenephosphonate $\left[\mathrm{M}_{2}\right]$ $\left(r_{1}=28.97, r_{2}=0.027\right)$.

この結果 DABP モノマーの反応性はとぼしいことが わかるが，モノアリルェステル型のモノマー,たとえば酢 酸アリルと MMA の共重合では $r_{1}=23, r_{2}=0$ また St とでは $r_{1}=90, r_{2}=0.01$ である ${ }^{8)}$ ここれよりもジアリル エステルの DABP の反応性はやや大といえる。

一方 Beynon $^{3)}$ による DABP とメタクリル酸ラウリ ル (LMA) の共重合の結果は $r_{1}=19.5, r_{2}=0.072$ で, 筆者らの MMA との $r_{1}=22.96, r_{2}=0.135$ とでは $r_{2}$ 值に相当の差が恋められる。これは MMA 上 LMA モ ノマーとを比べる々，後者のラウリル基はメチル基に比 して立体碚守を起こしやすく，LMA どうしの反応が抑 制されるためと考えられる。

与えられたラジカルに対する異種モノマーと, 同種モ ノマー上の反応性の相対的な值 $1 / r_{2}$ を酢酸了リルと DABPについて比較すると，後者のモノマーが小であ る。このことはモ,マー分子の二重結合に及ぽす圆換基 の効果がフェニルホスホノ基 $\left(\mathrm{C}_{6} \mathrm{H}_{5} \mathrm{P}(\mathrm{O})\right.$-) よりもア七チ ル基の方が大であることを示している。

St との共重合の $r_{1} r_{2}$ 值から $Q-e$ 項を求めると, St の $Q=1.0, e=0$ とおくと影, DABP は $Q=0.78, e=$ +0.50 となり $e$ は酢酸ビニルの值と近似する。

\section{2 コポリマーの粘度}

コポリマーのベンゼン溶液 $(0.5 \mathrm{~g} / 100 \mathrm{cc})$ の $\eta_{s p} / c$ と モノマー組成との関係を Fig. 5 に示した。モノマー混 合物中の DABP の濃度が增加寸るに従って, 生成ポリ マーの粘度は低下する傾向を示し $\eta_{s p} / c$ と $\left[M_{2}\right]$ の間に

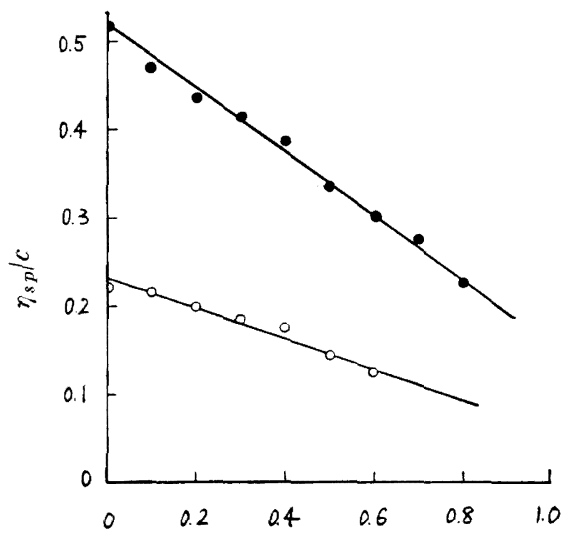

Mol fraction of DABP in feed $\left[\mathrm{M}_{2}\right]$ (Benzene soln. at $20^{\circ} \mathrm{C}, \mathrm{C}: 0.5 \mathrm{~g} / 100 \mathrm{ml}$ )

Fig. 5. Relationship between the viscosity of copolymers and mol fraction of diallyl benzenephosphonate (DABP) in monomer mixture.

は $\eta_{s p} / c=\left[\eta_{s p} / c\right]\left[M_{2}\right]=0-k\left[M_{2}\right] /\left(\left[M_{1}\right]+\left[M_{2}\right]\right)$ なる関俰が 認められる。ここで $k$ の值は, St との共重合における 場合よりも MMA との場合の方が大であった。コポリ マーの粘度低下は DABP のアリル基の重合性によるも のであって，一般に多くのアリル化合物について認めら れているように洤，生長過程において活性メチレンの連 鎖移動が起こりやすく，その結果 DABP の濃度が増加 すると重合度が低下するものと考えられる。このことは 前記のモノマー混合系中の DABP の濃度が大となると 初期重合物は油状物となることからもらかがえる。

\section{3 ポリマーの生成速度}

ポリマーの単位時間あたりの重合率は粘度に掞ける場 合と同様に，モノマー混合系中の DABP 濃度とともに 減少している。これは連鎖移動によって生じた新しいう ジカルは容易に再生長を行ないにくく重合が停止するた めと考えられる。

また, 一方この重合速度の遅延は St と DABP の共 重合を例にとって考えると, St と酢酸ビニルの場合に 認められているように"11)，モノマー混合系中の St モ， マーの濃度が小さい場合には St モノマーは DABP モ ノマーの重合に対して一種の抑制剤のような作用を示す ためではないかと考えられる。すなわちこの場合 DABP ラジカルは St モノマーの濃度が小さいにもかかわらず $1 / r_{2}$ の值が大きいために, St モ, マーと反応してポリマ 一の末端が St ラジカルになる確率が大で, ここに生じ た新しいSt ラジカルは比較的反応性が劣るから DABP モノマーをしん速に付加せず，その結果速鎖の遅延とな って現われる(この際 St モノマーは濃度が小であるた め反応する確萃が少ない。 
3.4 コポリマーの赤外線吸収スペクトル

共重合の初期においては DABP の 2 個のアリル基の らちの 1 個が重合反応にあずかり，他方のアリル基は重 合にあずからずにポリマー中に存在するとすれば、 コポ リマーのスペクトルで認められた 3020, 2975, 1645, 1420 $\mathrm{cm}^{-1}$ にそれぞれビニル基の吸収が認められねばならな い。ポリマーとモノマーのスペクトルを比較すると, ポ リマーにはこれらのビニル基の吸収が消失している。し たがって重合反応で DABP の 2 個のアリル基のうちの 1 個が重合し, 他の 1 個のアリル基はポリマー中に残存 すると考えるよりも 2 個のアリル基が重合にあずかった とする方が妥当のようである。また, この初期ポリマー はクロロホルム, ベンゼンなどの溶㓮に可溶であること から, コポリマーは三次元化せずに線状で, 主鎖の形成 にあずからないも5一つのアリル基は分子内で環化して いるものと推定される。

この推論は, Berlin ら ${ }^{12}$ がジフリルフェニルホスヒ ンオキサイドの重合反応で, また Beynon ${ }^{8)} の$ DABP と LMA の共重合反応で認められていることによって も妥当なものと考えられる。

付記：本研究に努力された津田正彦氏に感謝する。また， 原料の一部をご恵与賜わった三苭レーヨン株式会社に厚くお礼
申し上げる。な扮, 本研究は昭和 39 年 4 月, 日本化学会第 17 年会で発表したものである。

\section{文献}

1）橋本静信, 古川 功: 有合化誌, 16, 20(1958)

2) C. L. Arcus, R. J.S. Mattews: J. Chem. Soc., 4607 (1956)

3) K. I. Beynon: J. Polymer Sci., Part 1, 1, 3343 (1963)

4) 橋本静信, 古川 功, 柳川鉄之助: 工化, 64, 1682 (1961)

5) 高橋儀作：高化, 14, 151 (1957)

6) R. H. Wiley, E. E. Sale: J. Polymer Sci., 42, 491 (1960)

7) J.C. H. Hwa, L. Miller: J. Polymer Sci., 55, $197(1961)$

8) L. Y. Young: J. Polymer Sci., 54, 411(1961)

9）川端 成彬, 鶴田 禎二, 古川 淳二：工化, 65,60 (1962)

10) たとえば P. D. Bartlett, R. Altschul : J. Am. Chem. Soc., 67, 812, 816(1945)

11) C. Walling: J. Am. Chem. Soc., 71, 1930(1949)

12) K. D. Berlin, G. B. Butler: J. Am. Chem. Soc., 82, 2712(1960)

\title{
Copolymerization of Diallyl Benzenephosphonate and Methyl Methacrylate or Styrene
}

\author{
By Shizunobu Hashimoto* and Isao Furukawa*
}

The monomer reactivity ratios for the copolymerization of diallyl benzenephosphonate (DABP) and methyl methacrylate (MMA) or styrene (St), respectively, have been measured at $70^{\circ} \mathrm{C}$.

$$
\begin{array}{lll}
\text { MMA-DABP }, & r_{1}=22.96, & r_{2}=0.135 \\
\text { St-DABP }, & r_{1}=28.97, & r_{2}=0.027
\end{array}
$$

DABP is less active for copolymerization with MMA or St, but DABP is more active than that of other allylic compounds.

Viscosity have been measured for some copolymers and these values are found to depend on the phosphonate contents in the monomer mixtures.

The infrared spectra data of copolymers seems to indicate that DABP monomer propagates by a cyclic polymerization mechanism.

\footnotetext{
* Department of Applied Chemistry, Faculty of Engineering, Doshisha University (Kyoto)
} 